\title{
The glass ceiling in SMEs and its impact on firm managerialisation: a comparison between family and non-family SMEs
}

\author{
Lucrezia Songini \\ Economics and Business Department, \\ Eastern Piedmont University, \\ Via Perrone, 18, 28100 Novara (NO), Italy \\ E-mail: lucrezia.songini@eco.unipmn.it
}

\section{Luca Gnan*}

School of Economics,

Tor Vergata Rome University,

Via Columbia, 2, 00133 Rome, Italy

E-mail: luca.gnan@uniroma2.it

*Corresponding author

\begin{abstract}
This article aims at comparing family and non-family SMEs with regard to the role of women in ownership, governance and management roles and its relation with the firm managerialisation. We conducted a quantitative deductive design and tested the hypotheses through a questionnaire survey of 313 SMEs in Italy. Findings reveal that family SMEs are a more favourable context for breaking through the glass ceiling. Results also show that in non-family SMEs managerial mechanisms are more relevant when women are involved in governance and managerial roles. On the contrary, in family SMEs, our findings do not outline an active role of women in favouring firm managerialisation.
\end{abstract}

Keywords: SMEs; family and non-family firms; glass ceiling; governance roles; management roles; firm managerialisation.

Reference to this paper should be made as follows: Songini, L. and Gnan, L. (2014) 'The glass ceiling in SMEs and its impact on firm managerialisation: a comparison between family and non-family SMEs', Int. J. Business Governance and Ethics, Vol. 9, No. 2, pp.170-196.

Biographical notes: Lucrezia Songini is Associate Professor of Managerial Control Systems and Strategy and Management of Family Businesses at Eastern Piedmont University, Italy. She is an Adjunct Professor of Performance Measurement and Accounting and Control in SMEs at Bocconi University, Milan. Since 1990, at Bocconi School of Management she has been in charge of many executives and in company courses, and research projects. She is the Chair of the SIG (Special Interest Group) Entrepreneurship of EURAM (European Academy of Management), and of the track 'Accounting and control for sustainability' (SIG Business \& Society). She has published on topics related to family business, women entrepreneurs, sustainability, strategic cost management, performance measurement, after sales services and servitisation. 
Luca Gnan is Professor of Organisational Behaviour at Tor Vergata University. $\mathrm{He}$ is the President of the European Academy of Management (EURAM). He is member of the Central Evaluation Committee of the Tor Vergata University and board member of the Tor Vergata World University. He has been involved in various academic and public associations, including the Education Ethics Executive Committee of AOM (Academy of Management), AOM BPS Division Representative for Europe, AOM OMT Division Research Committee, Vice-President and Executive Director of EURAM (European Academy of Management), review board member of FERC (Family Enterprise Research Conference), Sub-theme Convenor of EGOS (European Group of Organizational Studies), and Stream Chair of CMS (Critical Management Studies). He has been guest editor of various journals, and he has published on topics related to family business governance, corporate and public governance, strategy formulation processes, and the role of models in decisional processes.

This paper is a revised and expanded version of a paper entitled 'Women in family and non family SMEs: the relationship with firm's managerialization and performance' presented at 12th Euram Conference, Rotterdam, 6-8 June 2012.

\section{Introduction}

Studies on gender in family firms and small and medium sized enterprises (SMEs) are developing (Cole, 1997; Harveston et al., 1997; Nelson and Levesque, 2007). Research on the role and involvement of women in this type of firms is still fragmentary, and little of it has been empirical (Danes and Olson, 2003). Brush et al. (2006) argued that the focus of research has shifted from early studies that questioned if gender made a difference, to the current focus on how gender issues impact on the experience of business ownership, governance, and management. General research on women focused mainly on their governance and managerial positions in medium-large companies (Grant, 1988; Singh et al., 2008; Nielsen and Huse, 2010; Torchia et al., 2012; Machold et al., 2013). Literature on family firms explored mainly women in ownership and in governance (Moore and Buttner, 1997; Gnan and Montemerlo, 2006). Only a few contributions studied women as top and executive managers in family firms, but they considered mostly how women can hold governance and managerial roles as a consequence of the succession process (Nelton, 1999; Cadieux et al, 2002; Curimbaba, 2002; Allen and Langowitz, 2003; Haberman and Danes, 2007). Therefore, a doublefold gap can be summarised. On the one hand, women's role in SMEs is not so much investigated, on the other hand, their contribution in family firms' top management teams represents a under developed issue as well.

Notwithstanding, the evidence of women's success in business (Jimenez, 2009), and women's increasing levels of higher education (Boarden and Nucci, 2000), research on the role of women in family firms and SMEs suggested also that the majority of women tends to remain in the background, frequently sharing the involvement in the family firm with the roles of household management and child-rearing (Cole, 1997). Literature highlighted that also in family firms and SMEs women face the 'glass ceiling' phenomenon (Veale and Gold, 1998; Arulampalam et al., 2007). The term 'glass ceiling' is generally used (Powell and Butterfield, 1994) to express the apparently transparent and 
impenetrable obstacles to women's evolution within top management/business elite positions. Indeed, such issue in family firms can be analysed by considering the role of women also in ownership and governance, and not only in management, as a consequence of the intertwined three circles which characterised family firms: ownership, family and management (Tagiuri and Davis, 1982; Gersick et al., 1997). In other words, family firms seem to represent a better situation for exploiting the opportunity of including women at all levels of the running of a business (Songini and Dubini, 2003). This topic has gained considerable interest with regard to family firms, since research argued that in such a context women contribute a great deal, such as new ideas, and transformations in management style and communication, leading to an increase in firm performance (Sharma, 2004). However, women are invisible in family firms (Salganicoff, 1990). In fact, they fulfil a subdued role, even though this role gives them the opportunity to have a peculiar perspective of the complex, emotional side of family involvement, as well as family and/or non-family members' dynamics (Lyman et al., 1995; Dumas, 1998).

This article focuses on the role of women in SMEs, both family and non-family ones. It aims at comparing family and non-family firms, with regard to the presence of the glass ceiling, on the one hand, and to the impact of women's role on how the firm is run, with particular emphasis on the managerialisation issues, on the other hand. Would family firms represent a better stage for women in order to break the glass ceiling? When the glass ceiling is broken, how women impact on the adoption of formal managerial mechanisms?

Firstly, we investigate if the 'glass ceiling' continues to bar women from advancing to governance and managerial roles in SMEs. We argue that in family SMEs women may play an important role not only in ownership, but also in governance and managerial positions. "Families that are involved in business - as well as others, such as scholars and consultants - must recognise this important role and not undervalue women's influence in the continuity of the family firm" [Jimenez, (2009), p.60]. However, previous studies on family firms outlined a low number of women in governance and managerial roles, verifying the presence of the glass ceiling (Songini and Gnan, 2009).

At the same time, we aim to understand how women's role in family firms and SMEs may affect how the firm is run (Dugan et al., 2008), with particular regard to the adoption of a larger set of managerial mechanisms than men perform, with a more formal approach. Thus, we propose that the level of 'managerialisation' may be related to the women's role in family firms and SMEs. In particular, we consider managerialisation associated with the adoption of formal mechanisms, such as formal strategic planning and managerial control systems (Songini and Gnan, 2009).

On the one side, a number of studies addressed the family firms' managerialisation (Songini, 2006), but without analysing the relationship between women and firm managerialisation. On the other side, previous results on female-owned and managed firms (Dumas, 1998; Vera and Dean, 2005) said little about how women run their family firms as top managers, with regard to the diffusion of formal governance and managerial mechanisms, strategy formulation processes, and organisational structures (Cliff, 1998). Nevertheless, accounting research highlighted the role of governance and top management teams in the adoption of managerial mechanisms (Zimmerman, 2006; Naranjo-Gil et al., 2009; Abernethy et al., 2010), but without considering gender issues. 
Therefore, we argue that the presence and the level of involvement of women in ownership, governance, and management of SMEs, especially family SMEs, will affect the managerialisation of the firm.

We conducted a quantitative, deductive design and tested our hypotheses through a questionnaire survey of 313 SMEs in Italy. Our findings reveal that family SMEs are a more favourable context for removing the glass ceiling, than non-family SMEs, even though it still remains an issue in top management and governance positions. Results also show that in non-family SMEs, when women are involved in governance and managerial roles, managerial mechanisms, such as strategic planning, budgeting and managerial reporting systems, are more used and relevant than in family SMEs.

The article has theoretical as well as empirical and practical contributions. From a theoretical point of view, main contributions regard the presence of the glass ceiling, as well as a relationship between women's involvement and firm's managerialisation, but in particular in non-family SMEs. The empirical contribution of this study concerns the characteristics of the sample, consisting of SMEs operating in Italy, that is recognised to be one of the most interesting contexts to study both SMEs and family firms.

Our study has practical implications for managerial purposes and for policymakers, too. It showed that for companies, particularly non-family owned ones, it could be convenient to favour female active participation, in terms of a more managerial approach to run the business.

Future directions concern especially the relationship between women's involvement in governance and management, and firm managerialisation, which represents an under investigated issue in family firms. Our evidence that family SMEs, with a relatively high involvement of women, do not adopt managerial mechanisms needs to be elaborated more in depth, in order to further investigate the managerialisation of family firms through the mediating role of women.

The article proceeds in five sections. Firstly, the theoretical mainstreams on the role of women and their impacts on managerialisation of SMEs and family firms are outlined. Secondly, research propositions and hypotheses are defined. Thirdly, the research design and methods are described. In Section 4, findings are presented. Finally, the discussion, contributions, and limitations of the article are presented.

\section{Theoretical streams}

This article refers to different literature streams, concerning, respectively, the role of women and the glass ceiling, on the one side, and firm managerialisation, on the other one.

\subsection{The role of women and the glass ceiling}

The term 'glass ceiling' refers to situations where the advancement of a qualified person within the hierarchy of an organisation is stopped at a lower level. Usually, this situation refers to some form of discrimination, most commonly sexism or racism. Evidence suggests that women are typically confronted by the 'glass ceiling'. Glass ceiling is an invisible barrier preventing their rise into leadership positions in enterprises (Kanter, 
1977; Morisson et al., 1987). Previous studies analysed in particular the role of women in family owned businesses, while the context of SMEs is still underdeveloped.

The literature on family firms focused mainly on women in ownership and in governance (Moore and Buttner, 1997), connecting their top roles as a consequence of the succession process (Nelton, 1999; Haberman and Danes, 2007; Cadieux et al., 2002; Curimbaba, 2002; Allen and Langowitz, 2003). Previous studies highlighted that family owned businesses should be more favourable contexts for removing the glass ceiling for women belonging to the owner family. However, they showed also the existence of the glass ceiling in family SMEs, but they particularly focused their governance and managerial roles (Songini and Gnan, 2009).

The role of the family in supporting an active role of women in family business is ambivalent (Cole, 1997). Studies on opportunities and constraints to the development of female-driven companies stressed the role of the family as the provider of psychological backing, the necessary network and the main financial resources (Coleman, 2000). The family can give a woman financial resources, consolidated relationships based on trust, knowledge and socialisation into the entrepreneurial culture. At the same time, it could be also a context of constraint and economic exploitation (Danes and Olson, 2003; Hamilton, 2006). Relatives connect themselves more with their role in the family (entrepreneur's wife, daughter, nephew, etc.) than with the firm (McGivern, 1978; Hollander and Bukowitz, 1990). Therefore, the same process of functional specialisation of activities, and the authority model typical of the family, are replicated inside the firm. Family firms are characterised by women's tendency to be in charge of operating and supporting roles, instead of managerial ones, as a consequence of patriarchy (Grant and Tancred, 1992). Generally, family rules are founded on gender differences, thus contributing to the invisibility of women's roles in family owned businesses (Barnes, 1988; Gillis-Donovan and Moynihan-Bradt, 1990). In family firms, women's invisibility refers to the fact that women's professional capabilities are generally not valued, as a result of both the discrimination, resulting from the diffused social bias against the female gender (Lyman, 1988; Rosenblatt et al., 1985; Rowe and Hong, 2000) and the socialisation process followed by women belonging to the family, which generally do not attend economics and business schools and do not make previous experience outside the family firm. This may make it difficult for women to develop the necessary attitudes for coping with managerial and governance roles (Salganicoff, 1990). Family firm structures and mechanisms could be in place to help women to cope with the conflict between work and family roles (especially in those of wife and mother) However, involvement in a family owned business can be a weak entrepreneurial choice for a woman, particularly when the company is inherited. Literature defines 'co-preneurship' as the context where a wife supports her husband, doing mostly administrative activities and secretarial work (Fitzgerald and Muske, 2002; De Bruin and Lewis, 2004). Many authors studied dualcareer couples, sibling relationships, and the challenges daughters face in family firms, highlighting that, notwithstanding their invisibility, women play a fundamental role in the day-to-day running of the business and the family (Marshack, 1994; Poza and Messer, 2001; Barnes, 1988; Dumas, 1989; Friedman, 1991; Ward and Aronoff, 1992). To conclude, we can say that previous studies showed that also in family business, and not only in non-family ones, women find difficulties to break through the glass ceiling. 


\subsection{Women's management styles and approaches to leadership and the relation with firm's managerialisation}

The literature on women in family firms mostly dealt with the characteristics of female entrepreneurship, but it did not investigate the features of firms managed by women (Hamilton, 2006). Previous studies showed that female entrepreneurs usually establish their firms in the service industry and run small firms, with lower levels of profitability (Anna et al., 1999; Du Rietz and Henrekson, 2000). Several contributions concerned women's management styles and their approaches to leadership (Brush, 1992). Mutual empowerment, collaboration, information sharing, empathy and nurturing characterise management styles in female-owned firms (Allen and Langowitz, 2003). These characteristics are typical of the so-called holistic manager (Jimenez, 2009). However, research seldom investigated the distinctive characteristics of firms owned and managed by women (Cuba et al., 1983; Carter et al., 1997; Cliff, 1998). Practically, no contributions analysed in depth the leadership style of women in family SMEs, focusing on how women run their family firms (Huse and Solberg, 2006; Jimenez, 2009).

On the other side, family business literature rarely analysed how managers, either professional, non-family members, or family members affect the adoption of managerial mechanisms. By contrast, in accounting and financial literature, managers, and in particular chief executive officers (CFOs), are generally considered to be in charge of the development and operation of management control systems (Zimmerman, 2006; Naranjo-Gil et al., 2009; Abernethy et al., 2010). In the start-up phase, the hiring of a finance manager is reported to be associated with the faster adoption of managerial control systems (Davila and Foster, 2005). Abernethy et al. (2010) found that senior management's leadership style is a significant predictor of the use of planning and control systems. However, accounting and finance studies did not consider the role of gender in the adoption of managerial mechanisms.

Finally, it is noteworthy that previous studies showed that family SMEs present a lower diffusion and less use of formal governance, strategic planning and managerial control systems than non-family firms (Songini and Gnan, 2013). However, a general agreement has not been found about the need, effects and model of managerialisation of family SMEs, notwithstanding many theories dealt with these subjects, such as: the stewardship theory (Davis et al., 1997); the resource-based view (RBV) of the firm theory (Habbershon and Williams, 1999); the organisational control theory (Hopwood, 1974; Galbraith, 1977); the agency theory (Ross, 1973; Jensen and Meckling, 1976); and the company growth theory (Rostow, 1960; Greiner, 1972; Normann, 1977). In particular, according to company growth theory, a SME which progresses through distinct stages as it develops (Churchill and Lewis, 1983; Scott and Bruce, 1987), comes to a critical stage, which requires the adoption of a more managerial approach. Also contingency research explained the use of managerial mechanisms in terms of a range of contextual factors, among which company size and ownership are considered relevant (Moores and Yuen 2001). According to Moores and Mula (2000, p.100), "family firms use a combination of clan, bureaucratic, and market controls. But there is more intense use of some forms of clan and bureaucratic controls than market controls". Therefore, family firms can be considered to be 'industrial clans', as they combine both bureaucratic and clan mechanisms of control (Ouchi and Price, 1978). 


\section{Research propositions and hypotheses}

Consistently with the aims of this paper, we propose two different groups of propositions and hypotheses, focused, respectively, on the role of women in family SMEs and the glass ceiling, and on the relation with firm's managerialisation.

\subsection{Women in ownership, governance and managerial roles: the glass ceiling}

The family firm context is friendly, allowing women to exploit their potential (Dumas, 1990). In fact, family firms give women opportunities to build flexible schedules (Dumas, 1992, 1998; Haynes et al., 1999), in order to combine their professional responsibilities with the household ones. They create a supportive context and more chance of accessing positions of responsibility, professional challenge, and opportunities for personal growth. Family relationships nurture a fruitful training ground for women for their interactions with customers, suppliers, and employees. Finally, a family firm is an ideal environment for preparing women for leadership, as they have a natural mentor, their father or mother. However, the literature and empirical evidence revealed that women's presence in ownership does not ensure a significant influence on a firm's decision-making processes. Moreover, women's presence in governance and managerial roles does not entail that they break through the glass ceiling, even in family firms, which are expected to be more favourable contexts (Aldrich, 1989; Songini and Dubini 2003; Songini and Gnan, 2009).

Accordingly, we hypothesise that family SMEs allow to break through the glass ceiling more than non-family firms. However, breaking the glass ceiling is not an intrinsic feature of family firms. It refers mainly to ownership (Aronoff, 1998; Gersick et al., 1999) than to governance and managerial roles. In fact, invisibility and the tendency of women to be in charge of operational and support roles, instead of managerial ones, characterise family firms (Cole, 1997; De Bruin and Lewis, 2004).

Accordingly, we suppose the presence of the glass ceiling in SMEs, but also that women in ownership, governance and managerial roles are more numerous in family SMEs than in non-family owned businesses.

Consequently, we propose the following two groups hypotheses:

A The glass ceiling in SMEs

- Hypothesis 1A (H1A): In SMEs, the number of women in ownership is smaller than that of men.

- Hypothesis 2A (H2A): In SMEs, the number of women in governance roles is smaller than that of men.

- Hypothesis 3A (HA): In SMEs, the number of women in managerial roles is smaller than that of men.

- Hypothesis 4A (H4A): In SMEs, the number of women in ownership is greater than that of women in governance roles.

- Hypothesis 5A (H5A): In SMEs, the number of women in governance is greater than that of women in managerial roles. 
B The glass ceiling in family and non-family SMEs

- Hypothesis 1B (H1B): In family owned firms, there are more women in ownership than in non-family owned businesses.

- Hypothesis 2B (H2B): In family owned firms, there are more women in governance roles than in non-family owned businesses.

- Hypothesis 3B (H3B): In family owned firms, there are more women in managerial roles than in non-family owned businesses.

\subsection{Women and firm's managerialisation}

According to agency theory, agency cost control mechanisms, such as strategic planning and managerial control systems, are relevant aspects of family firms' managerialisation (Songini and Gnan, 2013). The RBV theory applied to family firms highlights unique family-based resources and competitive advantage, leading to both a greater involvement of people - regardless of gender - in governance and managerial roles (Habbershon et al., 2003) and to a spreading of managerial mechanisms (Grant, 1991). According to the literature on managerial control systems, the board and top management take the decision to adopt formalised governance, strategic planning and managerial control systems (Abernethy et al., 2010). Recent research on women and family firms' performance states that women have a significant effect on the adoption of management practices (Danes et al., 2007).

Thus, we hypothesise that women in governance and managerial roles can influence how the firm is run and, thus, also the adoption of managerial systems. Moreover, according to RBV theory, family firms, allowing women to be in charge of governance and managerial roles, show a greater articulation of managerial systems, and an organisational culture more open to innovation and managerial consciousness (Songini and Gnan, 2009). In other words, they reveal higher levels of managerialisation. Therefore, in SMEs, especially in family firms, women's presence in governance and managerial roles has a relationship with the firm's managerialisation level.

In more detail, we propose two different groups of hypotheses. The first one concerns the relation between the role of women and firm's managerialisation in SMEs, while the second one focuses on differences between family and non-family SMEs.

1C Women and firm's managerialisation

- Hypothesis 1C (H1C): SMEs with a greater number of women in governance and managerial roles present higher levels of managerialisation.

2C Women and managerialisation in family and non-family SMEs

- Hypothesis 2C (H2C): In family owned firms with a greater number of women in governance and managerial roles the level of managerialisation is higher than in non-family owned firms. 
Table 1 Initial sample

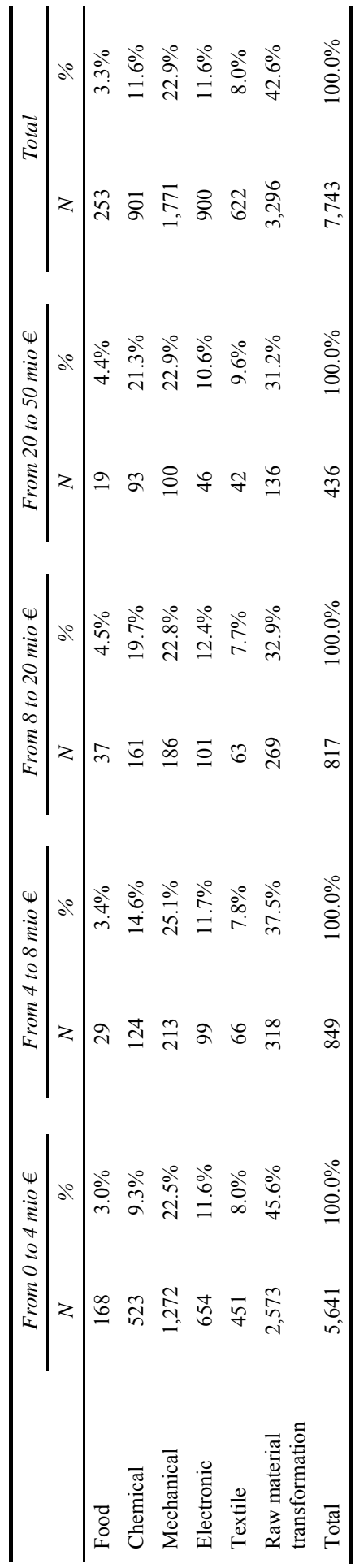




\section{Methods}

\subsection{Sampling frame}

Drawn from the AIDA database (Bureau Van Dijk Electronic Publishing), the initial sample comprised 7,743 SMEs from the province of Milan. The 7,743 SMEs were manufacturing incorporated companies, following the four-digit level of the ATECO91 Classification System. They were identified considering both revenues (from 0 to 50 million euros) and industry. The AIDA database contains balance sheet data from 1994 to 2009, on more than 1,084,774 incorporated SMEs, representative of the Italian manufacturing and non-manufacturing SME population. SMEs are independent firms ${ }^{1}$ :

- where not more than $25 \%$ of capital or voting rights is owned by one or more firms

- with fewer than 250 employees

- with either an annual turnover of up to 50 million euro, or an annual balance-sheet total not exceeding 43 million euro.

The choice of the province of Milan ensured the homogeneity of the sample, and a great representativeness of the Italian population of SMEs. In 2009, this province presented 111,488 firms which account for $10 \%$ of all Italian companies. The 7,743 companies were stratified by turnover and industry (Table 1).

\subsection{Sampling and data collection procedure}

The sampling and data collection procedure was accomplished in three phases. First, a single researcher pre-tested the preliminary version of the questionnaire with some senior SME executives attending training programmes in a major Italian business school. The pre-tests led to item revision, as well as the introduction of some new items. In the second phase, 15 on-site interviews with CEOs or executives of SMEs produced the final questionnaire version. In the third phase, the survey was mailed to 2,063 companies (mailing sample still stratified by turnover and industries), extracted from the initial sample, and following the sampling frame described above. Following Dillman (1978), two follow-up letters and one replacement questionnaire were mailed after the initial mailing. A single informant was used for each questionnaire. The cover letter requested that the survey be completed either by the CEO, or by a senior executive (co-CEO) with overall responsibility for strategic management issues (Alvarez and Svejenova, 2005). Although the use of multiple respondents would have reduced concerns about potential response biases, respondents had to be knowledgeable about the firm and its competitive environment (Campbell, 1955). In a large sample study, identifying and obtaining responses from multiple well-informed respondents is extremely problematic. The key methodological solution in using a single respondent approach is to find the most appropriate one (John and Reves, 1982). Thus, we qualified our respondents as individuals in CEO or equivalent positions. In line with previous studies, we considered CEOs and co-CEOs as the best possible key informants, because they are knowledgeable about governance and related decisions on the adoption of agency cost control mechanisms, while at the same time they are also in a better position than others to report on governance and management (Zahra et al., 2000). The self-reporting method is a 
primary data collection tool in management studies (e.g., Boone and de Brabander, 1997; Podsakoff and Organ, 1986). This is particularly suitable for studies focused on process variables inside governance and management, because these variables are extremely difficult to measure without the use of self-reports (Daily et al., 2003; Pettigrew, 1992). Studying governance and management requires the collaboration of directors and top managers, and they are reticent about inviting researchers to investigate what happens inside the 'black box' (e.g., Pettigrew, 1992). Recent scandals may have also aggravated problems, because the risk of being subject to a shareholder lawsuit is greater nowadays than in the past (Daily et al., 2003).

In our study, we adopted some procedural remedies to reduce potential common method biases:

1 our cover letter guaranteed anonymity and confidentiality (Podsakoff et al., 2003)

2 dependent and independent variables in questionnaires were kept separate from each other (Parkhe, 1993)

3 we devoted careful attention to the wording of questions, in order to avoid vague concepts and to reduce item ambiguity (Tourangeau et al., 2000)

4 we stated clearly in the questionnaire that there were no right or wrong answers, and that respondents should answer questions as honestly as possible (Podsakoff et al., 2003)

5 we carefully worded questions to minimise the likelihood of a social desirability bias, using inputs from the pilot interviews.

\subsection{Sample achieved}

A total of 313 completed questionnaires were returned. The 15\% response rate is comparable with those of large-scale surveys involving executives (Powell and Dent-Micallef, 1997; Robertson et al., 1995). It is acceptable considering the setting of the survey (SMEs), the firms' diversity, the respondents' roles (CEO, president, executive chair, or managing director), and the sensitivity of the information. The response rate is higher with those normally obtained in Italy (Corbetta and Montemerlo, 1999; Giacomelli and Trento, 2005; Gnan et al., 2013).

Operationalisations of the family business concept differ on several dimensions: level of family involvement; level of family ownership; managerial involvement; and CEO perception of the firm being a family business (Westhead and Cowling, 1998, Sharma, 2004; Stoica and Pistrui, 2006). Corbetta (1995) defined a family firm as a company where one or more families, with family ties, relationships or solid alliances, own the majority of the capital, and where family members cover governance and managerial roles. We define a family firm as an enterprise meeting at least one of the following requirements (Gnan and Montemerlo, 2006):

$151 \%$ or more of the equity is owned by the family

2 the family owns less than $51 \%$, but controls the company in partnership with friends, other entrepreneurs, employees (e.g., an important mechanism that can serve purposes other than pure shareholding majority control is voting agreements whereby blockholders pool their voting rights) (see Corbetta, 1995; Villalonga and Amit, 2009; Bennedsen and Nielsen, 2008) 
3 respondents perceive the firm as a family firm, whatever the family share (Greenwald and Associates, 1995).

Of the 313 sampled firms, $241(77 \%)$ turned out to be family firms. In Table 2, some differences between family firms and non-family owned businesses are presented.

Table 2 Family vs. non-family firms (achieved sample)

\begin{tabular}{lcccccc}
\hline & \multicolumn{2}{c}{ Non-family firms } & & \multicolumn{2}{c}{ Family firms } \\
\cline { 2 - 3 } \cline { 5 - 6 } \cline { 5 - 6 } & Mean & Median & & Mean & Median \\
\hline Employees & 26.2 & 15.5 & & 21.5 & 13.0 \\
Male employees & 18.9 & 10.0 & & 15.4 & 10.0 \\
Female employees & 7.7 & 5.0 & & 6.8 & 4.0 \\
Foundation year & $1,980.3$ & $1,982.5$ & & $1,972.8^{* * *}$ & $1,977.0$ \\
\# of strategic business areas (SBAs) & 1.7 & 2.0 & & 1.6 & 1.0 \\
\hline
\end{tabular}

Note: $* * *$ sig. $<0.01$

We conducted two tests that showed the absence of sample biases. Firstly, we evaluated non-response biases with chi-square tests between our sample and the mailing list, finding no significant differences for industries $\left(\chi^{2}=0.0236895\right.$, df $\left.=7\right)$, turnover $\left(\chi^{2}=0.048472\right.$, df $\left.=5\right)$ and employees $\left(\chi^{2}=0.076877\right.$, df $\left.=3\right)$. Moreover, across industries, classes of turnover and classes of employees, the response rates vary, but proportions of respondents are not statistically different (Fisher's exact test) in the sample, or in the mailing list (industries vs. turnover, $\mathrm{p}=0.0199$; industries vs. employees, $\mathrm{p}=0.0298$; turnover vs. employees, $\mathrm{p}=0.03478$ ). We also compared early respondents (first half) with late respondents (second half), following the Armstrong and Overton (1977) procedure. No significant differences were found on key characteristics such as age of the company, size (employees and turnover), market conditions or industry characteristics, suggesting that non-response bias may not be a problem. The sample achieved represents a wide range of industries, and firm size, as shown in Table 3 . Moreover, in order to account for potential biases, the statistical analyses control for some sources of heterogeneity in the sample, as discussed below. The achieved sample presents a distribution fairly similar to that of the initial sample, thanks to the stratified extraction of 2,063 companies from the mailing sample, and to the three-phase sampling and data collection procedure. However, medium-sized enterprises are a bit overrepresented, as are the chemical and mechanical industries.

\subsection{Control for sources of sample heterogeneity}

\subsubsection{Industry}

While the focus of the study is on women in both family SMEs and non-family SMEs, their presence in governance and management, and managerialisation, there may still be various degrees of relatedness within these issues among different industries. ATECO91 measures, even at a four-digit level, are likely to suffer from aggregation biases. For example, different industries may be in different economic phases at the same time. It seems likely that belonging to different industries has different impacts on women's presence in governance and managerial roles, and managerialisation. 
Table 3 Achieved sample

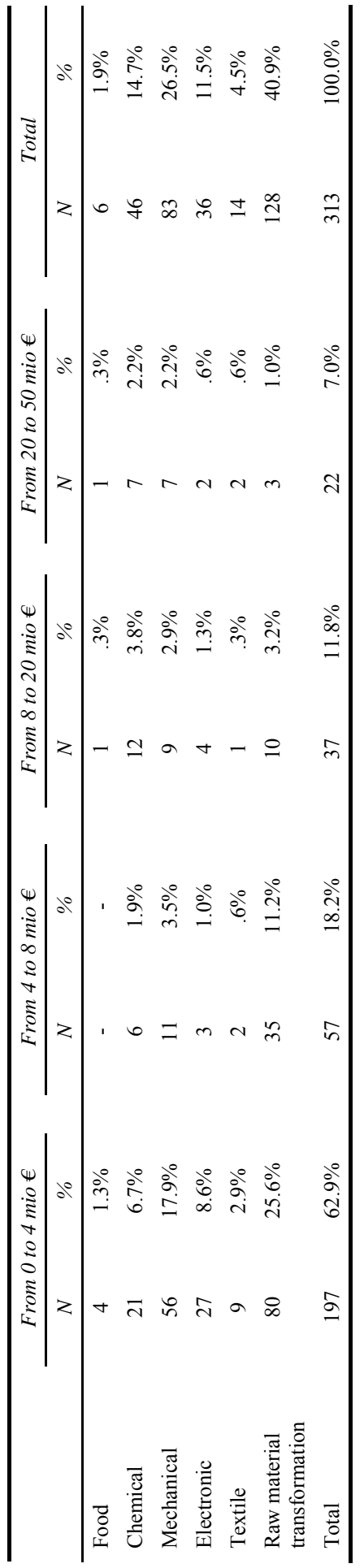




\subsubsection{Relative size of the firm}

Only a few authors have studied gender-related issues in SMEs (Brush, 1992; Cliff, 1998), considering, in particular, whether the role of women depends on the firm's size. As far as managerialisation is concerned, the use of formalised managerial control systems in non-family firms is relatively independent of firm size, while company size has an impact on the managerialisation of family firms (Speckbacher and Wentges, 2007). Exclusively owner-managed firms are more centralised and make less use of formalised managerial control systems. In partly owner-managed firms, a considerable impact of firm size is ascertained: the greater the number of employees, the greater decentralisation of the decision-making processes, and the more frequently managerial control systems are used (Speckbacher and Wentges, 2007).

\subsubsection{Age of the firm}

A small firm passes through distinct phases of development (Churchill and Lewis, 1983; Scott and Bruce, 1987), until it arrives at a critical point, which requires a more managerial approach, with the adoption of planning and managerial control systems. Following this perspective, we tested the influence of an eventual temporal heterogeneity of the sample.

Although we used standard control variables in the study, owing to the need to restrict the length of the questionnaire to achieve its primary purpose, our list of control variables was not as extensive as desired. For example, in contrast to Schulze et al. (2001), we did not control for capital intensity and industry growth. Although it is impossible to tell how a more extensive set of controls might have affected our results, we do note that aside from the above control variables, the study conducted by Schulze et al. (2001) shows that additional controls were either insignificant or mixed in their impact on governance structures.

\subsection{Measures}

\subsubsection{Women in ownership, governance and managerial roles}

The literature reveals a difference in the glass ceiling experienced by a woman, according to the role considered: owner, member of a governance mechanism, and manager. Most studies deal with the glass ceiling for women managers (Powell and Butterfield, 1994; Veale and Gold, 1998; Arulampalam et al., 2007). With regard to family firms, studies focused mostly on ownership and governance (Gnan and Montemerlo, 2001; Songini and Dubini, 2003; Songini and Gnan, 2009).

Women in ownership are measured considering the average number of women in shareholding, the percentage of women of total shareholders, women's ownership percentage, and the percentage of women majority holders.

In order to measure women in governance and managerial roles, we distinguish governance roles (Chairman, $\mathrm{CEO} / \mathrm{Sole} \mathrm{CEO}^{2}$, and Board Member) from the managerial ones (Managing Director, BU Director, and Functional Director: CFO/Administrative Director, Production Director, Sales Director, Purchasing Director), which are related to roles more involved in operational concerns. We use six variables: Chairman; CEO/Sole CEO; Board Member; Managing Director; Business Unit (BU) Director; and 
CFO/Administrative Director, Production Director, Sales Director, Purchasing Director. They are dichotomous variables based on responses to questions irrespective of whether the incumbent is male or female.

For each variable, we use a twofold version (a male and female one), where a score of ' 1 ' denotes the presence of a man/woman in each role, and a score of ' 0 ' otherwise.

\subsubsection{Firm managerialisation}

Recent studies report a relationship between the managerialisation of family firms and the adoption of bureaucratic control mechanisms (Songini et al., 2003; Songini and Gnan, 2013). Bureaucratic control systems comprise a range of diagnostic systems, such strategic planning, budgeting, reporting, and incentives (Simons, 2000). Strategic planning is a management tool for organising the present on the basis of the projections of the desired future. That is, a strategic plan is a road map for leading an organisation from where it is now to where it would like to be in the next years. The budget is a short-term financial plan for implementing the various decisions that management has made. The budgeting process communicates to everyone in the organisation the part that they are expected to play in implementing management's decisions. Reporting provides feedback about planned and actual company outcomes. The incentives aim to reinforce managers' performance evaluation.

To measure the level of managerialisation, we use four variables: strategic planning; budget; reporting; and incentives. They are dichotomous variables based on responses to questions about whether the firm uses each managerial mechanism. For each variable, a score of ' 1 ' denotes the presence of the managerial mechanism; a score of ' 0 ' otherwise.

\section{Findings}

In this section, we report and comment on the results regarding women's presence in ownership, governance and managerial roles in SMEs (family-owned SMEs and non-family ones), and its relationship with company managerialisation. We conducted multivariate analyses to control for various sources of heterogeneity in the sample, including in the analyses the control variables, but the results remained stable and robust.

\subsection{Women in ownership, governance and managerial roles: the glass ceiling in SMEs}

Hypotheses H1A, H2A and H3A state that in SMEs the number of women in ownership, governance and managerial roles is smaller than that of men. To test the presence of women in ownership, and to test if it differs significantly from that of men, for the entire sample of SMEs we used a paired sample T-test. Results highlight that the average number of male shareholders is 1.62 , while that of women in shareholding is 0.84 , and this difference is statistically significant $(\mathrm{sig} .=0.000)$. The percentage of women of total shareholders is $31 \%$, with respect to $59 \%$ of men, and $10 \%$ of other companies. Women's ownership percentage is 17.2 . Moreover, $44.4 \%$ of sample companies have at least one female shareholder, while only in $8.6 \%$ of enterprises women own the majority of shares (50\% plus one share). These findings show that the glass ceiling still exists with regard to 
ownership. A previous research on Italian SMEs, carried out in 2003, showed similar results (Songini and Dubini, 2003).

As far as governance and managerial roles is concerned, for the entire sample of SMEs and for each role, we compared the male and female percentages of presence. Table 4 reports these percentages and the significance of the percentages' differences (paired sample T-tests). We can see that in SMEs, men are mostly in charge of governance and managerial roles, with the exception of the role of $\mathrm{CFO} /$ Administrative Director, where the presence of women $(54.8 \%)$ is a bit higher than that of men.

With respect to the role of board member, findings reveal that the average number of men $(2.48)$ is significantly (sig. $=0.000)$ higher than the presence of women on the board (0.84).

Consequently, hypotheses $\mathrm{H} 1 \mathrm{~A}, \mathrm{H} 2 \mathrm{~A}$, and H3A are verified, confirming that the glass ceiling is an issue characterising, not only large companies, but also SMEs, and that it affects ownership, governance and managerial roles.

Table 4 Women in governance and management

\begin{tabular}{lccc}
\hline & $\%$ of women & $\%$ of men & Sig. \\
\hline Chairperson & $14.7 \%$ & $85.3 \%$ & $* * *$ \\
Sole CEO & $12.3 \%$ & $87.7 \%$ & $* * *$ \\
CEO & $14.1 \%$ & $85.9 \%$ & $* * *$ \\
Managing director & $12.9 \%$ & $87.1 \%$ & $* * *$ \\
BU director & $6.7 \%$ & $93.3 \%$ & $* * *$ \\
CFO & $54.8 \%$ & $45.2 \%$ & \\
Production director & $7.8 \%$ & $92.2 \%$ & $* * *$ \\
Sale director & $19.2 \%$ & $80.8 \%$ & $* * *$ \\
Purchase director & $34.4 \%$ & $65.6 \%$ & $* * *$ \\
\hline
\end{tabular}

Note: $* * *$ sig. $<0.01$

As far as hypothesis $\mathrm{H} 4 \mathrm{~A}$ is concerned, which states that the presence of women is greater in ownership than in governance roles, we compared the average number of women shareholders with the average number of women among board members. Results of the paired sample T-test show that the presence of women in ownership (86\%) is not significantly different from the presence of women in governance roles $(86 \%)$.

However, we found partially significant results concerning the presence of women in governance, compared with their presence in managerial roles (Hypothesis H5A). For the entire sample of SMEs, we compared each managerial role with each governance role filled by women. We tested (paired sample T-tests) 18 differences (Managing Director vs. Chairman; Managing Director vs. CEO/Sole CEO; Managing Director vs. Board Member; BU Director vs. Chairman; BU Director vs. CEO/Sole CEO; BU Director vs. Board Member; Functional Director (CFO/administrative director, production director, sales director, purchase director) vs. Chairman; Functional Director (CFO/administrative director, production director, sales director, purchase director) vs. CEO/Sole CEO; and Functional Director (CFO/administrative director, production director, sales director, purchase director) vs. Board Member). Hypothesis H5A is verified only for Bu directors and the functional directors, especially the $\mathrm{CFO}$ /administrative director and the purchase one, which include a greater percentage of women than in governance roles. These results 
confirm the tendency of women to be in charge of mostly operational and support roles (Grant and Tancred, 1992; Ufuk and Ozgen, 2001) (Table 5).

Table 5 Women in governance and managerial roles: a comparison

\begin{tabular}{llccc}
\hline & & \multicolumn{3}{c}{ Governance roles } \\
\cline { 3 - 5 } & & Chairperson & CEO-Sole CEO & Board member \\
\hline Managerial & Managing director & $0.12 / 0.19$ & $0.10 / 0.08$ & $0.11 / 0.23^{*}$ \\
& BU director & $0.04 / 0.17$ & $0.04 / 0.09$ & $0.05 / 0.10$ \\
& CFO/administrative & $0.53 / 0.16^{* * *}$ & $0.57 / 0.12^{* * *}$ & $0.51 / 0.30^{* * *}$ \\
& director & & & \\
& Production director & $0.07 / 0.17$ & $0.07 / 0.10$ & $0.08 / 0.20^{*}$ \\
& Sales director & $0.22 / 0.16$ & $0.21 / 0.11^{* *}$ & $0.19 / 0.19$ \\
& Purchase director & $0.35 / 0.15^{* * *}$ & $0.34 / 0.13^{* * *}$ & $0.31 / 0.26$ \\
\hline
\end{tabular}

Notes: $* * *$ sig. $<0.01 ; * *$ sig. $<0.05 ; *$ sig. $<0.1$

As far as Hypotheses $\mathrm{H} 1 \mathrm{~B}, \mathrm{H} 2 \mathrm{~B}$ and $\mathrm{H} 3 \mathrm{~B}$ are concerned, stating that in family owned businesses there are more women in ownership, governance and managerial roles than in non-family owned firms, they are verified with regard to the presence of women in ownership (Hypothesis H1B). We found that the percentage of women in ownership in family firms $(29 \%)$ is significantly (sig. $=0.000)$ higher than the percentage of women in ownership in non-family firms $(10 \%)$.

Table 6 Women in governance and managerial roles in family and non-family firms

\begin{tabular}{lccc}
\hline Roles & $\begin{array}{c}\text { Family businesses } \\
(\%)\end{array}$ & $\begin{array}{c}\text { Not family businesses } \\
(\%)\end{array}$ & Sig. \\
\hline Chairperson & 19.2 & 2.6 & $* * *$ \\
CEO-Sole CEO & 12.8 & 9.8 & $* * *$ \\
Board member & 33.7 & 7.1 & $* * *$ \\
Managing director & 16.4 & 0.0 & $* *$ \\
BU director & 4.8 & 14.3 & 34.6 \\
CFO/ administrative director & 61.5 & 7.1 & 1.5 \\
Production director & 8.0 & 23.1 & \\
Sales director & 21.4 & 35.9 & \\
Purchase director & & & \\
\hline
\end{tabular}

Notes: ***sig. $<0.01 ; * *$ sig. $<0.05$

With respect to the involvement of women in governance and management for each governance and managerial role, we compared the percentages of females in family owned and non-family owned firms (Table 6). We found significant differences (ANOVA tests for each female role between non-family firms and family firms) with respect to the involvement of women on the board of directors as chairman and board member, and with regard to the managerial roles of the managing director and $\mathrm{CFO}$ /administrative director. Therefore, hypothesis $\mathrm{H} 2 \mathrm{~B}$ is verified, while hypothesis $\mathrm{H} 3 \mathrm{~B}$ is only partially verified. These findings highlight that family firms are a more favourable context for female involvement, both in governance and in management. It is 
interesting that in family firms women are in charge not only of operational and support roles, but they also run the company as managing director. This result only partially confirms theories about the invisibility of women in family firms that suppose that women do mostly administrative activities and secretarial work (De Bruin and Lewis, 2004).

\subsection{Women and firm managerialisation}

This part of our research aimed at verifying the relationship between women's presence in governance and managerial roles in SMEs, and the firm's managerialisation level.

Hypothesis H1C states that SMEs with a greater number of women in governance and managerial roles present higher levels of managerialisation. This hypothesis is not verified (Table 7).

Table 7 Women and firm managerialisation in SMEs

\begin{tabular}{lcc}
\hline \multirow{2}{*}{$\begin{array}{l}\text { Managerial } \\
\text { mechanisms }\end{array}$} & \multicolumn{2}{c}{ Firms with women in governance and managerial roles } \\
\cline { 2 - 3 } No & Sig. \\
\hline Strategic planning & $40.00 \%$ & $41.26 \%$ \\
Budget & $67.00 \%$ & $73.00 \%$ \\
Reporting & $54.00 \%$ & $61.00 \%$ \\
Incentives & $37.00 \%$ & $41.00 \%$ \\
\hline
\end{tabular}

Notes: $* * *$ sig. $<0.01 ; * *$ sig. $<0.05 ; *$ sig. $<0.1$

Moreover, Hypothesis H2C (in family owned firms with a greater number of women in governance and managerial roles the level of managerialisation is higher than in non-family owned firms) is not verified with respect to family firms, but it is confirmed in non-family businesses, with regard to the presence of strategic planning and budgeting and, to a lesser extent, the reporting system (Table 8). Our findings are different from those of previous studies (Songini and Gnan, 2009), that outlined, in family firms, a positive relationship between the number of women in governance and managerial roles, and the level of managerialisation, with respect to the presence of reporting systems and incentives.

Instead, our results are consistent with the literature on managerial control systems that highlights the role of the board and top management in firms' managerialisation (Abernethy et al., 2010). However, they show that women managers and board members take the decision to adopt managerial mechanisms in non-family firms, rather than in family ones. These findings could be related to the fact that in family firms managerial mechanisms are less widespread than in non-family businesses, as a consequence of a management style more consistent with clan and social control (Ouchi, 1979, 1980; Moores and Mula, 2000). Moreover, in non-family businesses, people appointed in managerial and governance roles are more probably chosen according to their competencies, capabilities and attitudes, than in family firms, where family ties play a significant role (Astrachan and Kolenko, 1994). Thus, we can suppose that women managers in non-family firms are more willing to adopt a more formalised management style. 
Table 8 Women and firm managerialisation in family and non-family SMEs

\begin{tabular}{lccc}
\hline \multirow{2}{*}{$\begin{array}{l}\text { Managerial } \\
\text { mechanisms }\end{array}$} & \multicolumn{2}{c}{ Firms with women in governance and managerial roles } & \multirow{2}{*}{ Sig. } \\
\cline { 2 - 4 } & Non-family firms & Family firms & $* * *$ \\
\hline Strategic planning & $69.57 \%$ & $36.28 \%$ & $* * *$ \\
Budget & $91.00 \%$ & $69.00 \%$ & $*$ \\
Reporting & $77.00 \%$ & $57.00 \%$ & \\
Incentives & $50.00 \%$ & $39.00 \%$ & \\
\hline
\end{tabular}

Notes: $* * *$ sig. $<0.01 ; * *$ sig. $<0.05 ; *$ sig. $<0.1$

\section{Discussion and conclusions}

Our results confirm that the glass ceiling affects ownership, governance and managerial roles, both in family and non-family SMEs. In fact, we found that the average number of female shareholders is significantly lower than that of men, as well as the percentage of women of total shareholders, women's ownership percentage and the percentage of enterprises where women own the majority of shares. Moreover, in SMEs, men are mostly in charge of governance and managerial roles, with the exception of the role of $\mathrm{CFO} /$ administrative director. For women, breaking the glass ceiling is relatively easier with regard to ownership and governance roles, while it is more difficult for managerial roles, with the exception of the posts of $\mathrm{CFO} /$ administrative director and purchase director. These results confirm the tendency of women to be in charge of mostly operational, clerical and support roles in SMEs. However, if we consider family firms, we found that the glass ceiling is broken, with regard to ownership, and in part also governance and management. With respect to the involvement of women in governance and management, in family businesses they are more in charge of the governance positions of chairman and board member, and of the managerial roles of managing director and $\mathrm{CFO} /$ administrative director. These findings are interesting because they highlight that in family firms women are in charge not only of operational and support roles, as highlighted by previous studies, but they also run the company as managing director. Thus, theories about the invisibility of women in family firms, that suppose that women do mostly administrative activities and secretarial work (De Bruin and Lewis, 2004) are less valid in family firms.

As far as the relationship between women and firm managerialisation is concerned, our results show a relationship between women's involvement and firm managerialisation in non-family firms, with regard to the presence of strategic planning and budgeting and, to a lesser extent, reporting. These results are quite different from findings of previous studies (Songini and Gnan, 2009). In fact, they outlined, in family firms with a greater number of women in governance and managerial roles, a higher level of managerialisation than in non-family businesses, with respect to the presence of reporting systems and incentives. These previous findings showed a need for women in family firms to use managerial systems focused on the results obtained, in order to certify their contribution and not be perceived as merely the entrepreneurs' daughters, mothers or wives. On the contrary, our results do not reveal, in family firms, an active role of women in favouring firm managerialisation, even though they are in charge of the post of managing director. In fact, even though we have found that family firms are a more 
favourable context for female involvement in governance and managerial roles, when women break the glass ceiling they do not influence the adoption of managerial mechanisms. This could be a consequence of both women's management styles and approaches to leadership, which are more consistent with the 'holistic' manager (Jimenez, 2009), and the less formalised management style of family firms, based more on clan and social control systems than administrative ones (Moores and Mula, 2000). On the contrary, our results highlight that in non-family businesses, even though women find more difficulties in breaking the glass ceiling, when they reach management and governance positions, they impact on the level of firm managerialisation. This evidence can be the consequence of policies of manager selection, assessment, compensation and career, which are more likely based on formalised and objective considerations, and on people's competencies, skills and capabilities (Reid and Adams, 2001). However, in family firms women, as well as other family members, could be appointed to management and governance roles, mainly as a consequence of family and emotional ties, with the result that they may not have the competencies required to make the firm more managerial (Reid et al., 2002).

To conclude, our results seem to be consistent with those studies that highlighted that female entrepreneurs, in family firms, follow evolutionary and incremental approaches in establishing and managing their companies, consistent with clan and social control systems, rather than intentional and rationale strategies, related to administrative and diagnostic control. Weak female entrepreneurship in family firms and the stronger role of women managers in non-family businesses seem to point out a relevant role of firm context in favouring both breaking the glass ceiling, and the active role of women on the board and in top management team. Non-family businesses that are supposed to follow more formalised management styles, organisation structures, policies and mechanisms, and to be more selective in promoting people in management and governance position, are a less favourable context to break the glass ceiling. However, when this is broken, these companies seem to be an organisational context more favourable in allowing female managers to positively influence firm managerialisation. On the contrary, in family firms, women do not positively influence the adoption of managerial mechanisms, even though it is easier for them to hold governance and management posts.

From a theoretical point of view, the main contribution of this research regards the presence of the glass ceiling in SMEs, especially in non-family ones. With respect to the relationship between women's involvement in governance and management, and firm managerialisation our findings, show that the presence of women seems to attract a wider adoption of managerial mechanisms as a better explicit mean of accreditation of the competencies needed to run the different organisational positions. However, this is true only in non-family firms. Thus, our evidence that family SMEs, with a relatively high involvement of women, do not adopt managerial mechanisms needs to be elaborated more in depth, to further investigate the mediating role of women in the managerialisation of family firms. An empirical contribution of this study concerns the characteristics of the analysed sample, consisting of family SMEs operating in Italy, which is recognised to be one of the most interesting contexts in which to study family firms.

Our study has practical implications for managerial purposes and for policymakers. It showed that for companies, particularly non-family owned ones, it could be convenient to favour female active participation, in terms of a more managerial approach to run the 
business. However, this requires a careful planning of governance structures and recruitment, evaluation and promotion policies. In family firms, breaking the glass ceiling requires the active involvement of women, not just as co-owners, but also in governance and management roles. However, on the one hand, if their involvement needs to be real and not just formal, it is necessary for women to be eager and prepared to deal with the discipline that running a company requires. In fact, family SMEs' professionalisation does not necessarily pass through women's involvement, but it can be managed by professional managers with appropriate competencies and capabilities, and with no regard for gender (Songini \& Gnan, 2009). On the other hand, companies have to allow women to be in charge, not only of support roles, but also of top management roles, such as managing director, if they would like to exploit all the benefits coming from removing the glass ceiling. Women pursuing a professional or entrepreneurial career should ask for a higher level of involvement in governance and managerial roles, knowing that mere ownership - although very important - does not automatically grant equal opportunities. Policymakers interested in developing equal opportunity measures should encourage companies to plan their governance structures carefully, and to manage succession processes, in order to allow women the same opportunities as men in occupying managerial roles. On the other hand, they should encourage women entrepreneurs to acquire a level of managerial capabilities and skills that can allow them to reach governance and top management positions, and to contribute positively to company managerial mechanisms, style and performance.

As far as the limitations of the research are concerned, the redemption rate appears to be quite low if compared with North American and other countries' surveys. However, it is noteworthy to underline that it is in line with rates normally obtained in Italy and other European countries. A second limitation relates to the fact that the research was conducted on Italian SMEs. Studies on other countries might show different patterns of the presence of women, and/or they might give different results to hypotheses' testing, owing to the influence of national culture (Hofstede and Bollinger, 1987; Davidson and Burke, 2004; Gupta et al., 2008). Thirdly, the sample, focusing on manufacturing firms (although many different manufacturing industries were included), limits the possibilities for the generalisation of results. Studies including non-manufacturing firms could extend our findings. Then, it is noteworthy to point out that our research was carried out in 2010. This fact could have had an effect on our findings, considering that our sample consisted of SMEs that have been impacted significantly by the recent economic crisis.

Finally, several issues concerning the role of women and family firms' managerialisation would merit more detailed scrutiny. We considered the presence of women directors and managers, but did not test whether a critical mass has to be reached, in terms of the number of women in governance and management roles, in order to let them have a real influence on strategy, decision-making processes and firm performance (Torchia et al., 2012). Future research could test our results further, through the mediating role of female involvement, considering also evidence of critical mass theory. Moreover, although heterogeneity in a sample is a condition for empirical generalisation, industry- or country-level studies would be useful to validate these results. For example, additional research could usefully compare the relevance of the theories of women's presence in large family firms and services. In this latter aspect, many studies suggest that large family firms are different from small ones. Future research should take into account different family and ownership characteristics, composition, and dynamics, the 
generation involved in the business, and the features of the succession process (if any), in order to consider different kinds of family firm context and evolution.

\section{References}

Abernethy, M.A., Bouwens, J. and Van Lent, L. (2010) 'Leadership and control system design', Management Accounting Research, Vol. 21, No. 1, pp.2-16.

Aldrich, H. (1989) 'Networking among women entrepreneurs', in Hagan, O., Rivchum, C. and Sexton, D.L. (Eds.): Women Owned Businesses, pp.103-132, Praeger, New York,

Allen, I.E. and Langowitz, N.S. (2003) Women in Family-Owned Businesses, August, Center for Women's Leadership, Babson College, Mass Mutual Financial Group, Springfield, MA.

Alvarez, J.L. and Svejenova, S. (2005) Sharing Executive Power: Roles and Relationships at the Top, Cambridge University Press, Cambridge.

Anna, A.L., Chandler, G.N., Jansen, E. and Mero, N.P. (1999) 'Women business owners in traditional and non-traditional industries', Journal of Business Venturing, Vol. 15, No. 3, pp.279-303.

Armstrong, J.S. and Overton, T.S. (1977) 'Estimating non-response bias in mail surveys', Journal of Marketing Research, Vol. 14, No. 3, pp.396-402.

Aronoff, C.E. (1998) 'Megatrends in family business', Family Business Review, Vol. 11, No. 3, pp.181-185.

Arulampalam, W., Booth, A. and Bryan, M. (2007) 'Is there a glass ceiling over Europe? Exploring the gender pay gap across the wages distribution', Industrial and Labor Relations Review, Vol. 60, No. 2, pp.163-186.

Astrachan, J.H. and Kolenko, T.A. (1994) 'A neglected factor explaining family business success: human resource practices’, Family Business Review, Vol. 7, No. 3, pp.251-262.

Barnes, L.B. (1988) 'Incongruent hierarchies: daughters and younger sons as company CEO', Family Business Review, Vol. 1, No. 1, pp.9-21.

Bennedsen, M. and Nielsen, K.M. (2008) The Principle of Proportional Ownership, Investor Protection, and Firm Value in Western Europe, Working Article, Copenhagen Business School.

Boarden, R.J. and Nucci, A.R. (2000) 'On the survival prospects of men's and women's new business ventures', Journal of Business Venturing, Vol. 15, No. 4, pp.347-362.

Boone, C. and de Brabander, B. (1997) 'Self-reports and CEO locus of control research: a note', Organization Studies, Vol. 18, No. 6, pp.949-971.

Brush, C. (1992) 'Research on women business owners: past trends, a new perspective and future directions', Entrepreneurship Theory and Practice, Vol. 16, No. 4, pp.5-30.

Brush, C.G., Carter, N.M., Gatewood, E.J., Greene, P.G. and Hart, M.M. (Eds.) (2006) Growth-Oriented Women Entrepreneurs and their Businesses: A Global Research Perspective, Edward Elgar, London.

Cadieux, L., Lorrain, J. and Hugron, P. (2002) 'Succession in women-owned family businesses: a case study', Family Business Review, Vol. 15, No. 1, pp.17-30.

Campbell, D.T. (1955) 'The informant in quantitative research', American Journal of Sociology, Vol. 60, No. 4, pp.339-342.

Carter, N.M., Williams, M. and Reynolds, P.D. (1997) 'Discontinuance among new firms in retail: the influence of initial resources, strategy, and gender', Journal of Business Venturing, Vol. 12, No. 2, pp.125-145.

Churchill, N. and Lewis, V. (1983) 'The five stages of small business growth', Harvard Business Review, Vol. 61, No. 3, pp.30-50.

Cliff, J.E. (1998) 'Does one size fit all: exploring the relationship between attitudes towards growth, gender and business size', Journal of Business Venturing, Vol. 13, No. 6, pp.523-542. 
Cole, P. (1997) 'Women in family business', Family Business Review, Vol. 10, No. 4, pp.353-371.

Coleman, S. (2000) 'Access to capital and terms of credit: a comparison of men owned and women owned small businesses', Journal of Small Business Management, Vol. 38, No. 3, pp.17-52.

Corbetta, G. (1995) Le imprese familiari: caratteri originali, varietà e condizioni di sviluppo, Egea, Milano.

Corbetta, G. and Montemerlo, D. (1999) 'Ownership, governance and management issues in small and medium sized family businesses: a comparison of Italy and the United States', Family Business Review, Vol. 12, No. 4, pp.361-374.

Cuba, R., Decenzo, D. and Anish, A. (1983) 'Management practices of successful female business owners', American Journal of Small Business, Vol. 82, No. 2, pp.40-45.

Curimbaba, F. (2002) 'The dynamics of women's roles as family business managers', Family Business Review, Vol. 15, No. 3, pp.239-252.

Daily, C.M., Dalton, D.R. and Cannella, A.A. (2003) 'Corporate governance: decades of dialogue and data', Academy of Management Review, Vol. 28, No. 3, pp.371-382.

Danes, S.M. and Olson, P.D. (2003) 'Women's role involvement in family businesses, business tensions, and business success', Family Business Review, Vol. 16, No. 1, pp.53-68.

Danes, S.M., Stafford, K. and Loy, J.T. (2007) 'Family business performance: the effects of gender and management', Journal of Business Research, Vol. 60, No. 10, pp.1058-1069.

Davidson, M. and Burke, R. (2004) Women in Management Worldwide, Ashgate, Farnham, UK.

Davila, A. and Foster, G. (2005) 'Management accounting systems adoption decisions: evidence and performance implications from early-stage/start-up companies', The Accounting Review, Vol. 80, No. 4, pp.1039-1068.

Davis, J.H., Schoorman, F.D. and Donaldson, L. (1997) 'Toward a stewardship theory of management', Academy of Management Review, Vol. 22, No. 1, pp.20-47.

De Bruin, A. and Lewis, K. (2004) 'Toward enriching united career theory: familial entrepreneurship and co-preneurship', Career Development Journal, Vol. 9, No. 7, pp.638-646.

Dillman, D. (1978) Mail and Telephone Surveys: The Total Design Method, Wiley, New York.

Du Rietz, A. and Henrekson, M. (2000) 'Testing the female underperformance hypothesis', Small Business Economics, Vol. 14, No. 1, pp.1-10.

Dugan, A.M., Krone, S.P., LeCouvie, K., Pendergast, J.M., Kenyon-Rouvinez, D.H. and Schuman, A.M. (2008) A Woman's Place: The Crucial Roles of Women in Family Business, Family Business Consulting Group, Marietta, GA.

Dumas, C. (1989) 'Understanding of father-daughter and father-son dyads in family-owned businesses', Family Business Review, Vol. 2, No. 1, pp.31-46.

Dumas, C. (1990) 'Preparing the new CEO: managing the father-daughter succession process in family businesses', Family Business Review, Vol. 3, No. 2, pp.169-181.

Dumas, C. (1992) 'Integrating the daughter into family business management', Entrepreneurship: Theory \& Practice, Vol. 16, No. 4, pp.41-56.

Dumas, C. (1998) 'Women's pathways to participation and leadership in the family-owned firm', Family Business Review, Vol. 11, No. 3, pp.219-228.

Fitzgerald, M.A. and Muske, G. (2002) 'Copreneurs: an exploration and comparison to other family businesses', Family Business Review, Vol. 15, No. 1, pp.1-16.

Friedman, S. (1991) 'Sibling relationships and intergenerational succession in family firms', Family Business Review, Vol. 4, No. 1, pp.3-20.

Galbraith, J.R. (1977) Organization Design, Addison Wesley, Boston.

Gersick, K.E., Davis, J.A., McCollom Hampton, M.M. and Lansberg, I. (1997) Generation to Generation: Life Cycles of the Family Business, Harvard Business School Press, Boston, MA.

Gersick, K.E., Lansberg, I., Desjardins, M. and Dunn, B. (1999) 'Stages and transitions: managing change in the family business', Family Business Review, Vol. 12, No. 4, pp.287-297. 
Giacomelli, S. and Trento, S. (2005) Proprietà, controllo e trasferimenti nelle imprese italiane. cosa è cambiato nel decennio 1993-2003, Working Papers, no. 550, Bank of Italy, Rome.

Gillis-Donovan, J. and Moynihan-Bradt, C. (1990) 'The power of invisible women in the family business', Family Business Review, Vol. 3, No. 2, pp.153-167.

Gnan, L. and Montemerlo, D. (2001) 'Structure and dynamics of ownership, governance and strategy: role of family and impact on performance in Italian SMEs', Research article DIR, SDA Bocconi School of Management, Milan.

Gnan, L. and Montemerlo, D. (2006) 'Family-firm relationships in Italian SMEs: ownership and governance issue in a double-fold theoretical perspective', in Poutziouris, P.Z., Smyrnios, K.X. and Klein, S.B. (Eds.): Handbook of Research on Family Business, pp.501-516, Edward Elgar, Cheltenham, UK \& Northampton, MA, USA.

Gnan, L., Montemerlo, D. and Huse, M. (2013) 'Governance systems in family SMEs. The substitution effects between family councils and corporate governance mechanisms', Journal of Small Business Management [online] http://onlinelibrary.wiley.com/doi/10.1111/jsbm. 12070/abstract.

Grant, J. (1988) 'Women as managers: what they can offer to organisation', Organizational Dynamics, Vol. 16, No. 3, pp.56-63.

Grant, J. and Tancred, P. (1992) 'A feminist perspective on state bureaucracy', in Mills, A. and Tancred, P. (Eds.): Gendering Organizational Analysis, Sage, London.

Grant, R.M. (1991) 'The resource-based theory of competitive advantage: implication for strategy formulation', California Management Review, Vol. 33, No. 3, pp.114-135.

Greenwald and Associates (1995) 1995 Research Findings, Massachusetts Mutual Life Insurance Company, Springfield, MA.

Greiner, L.E. (1972) 'Evolution and revolution as organization growth', Harvard Business Review, Vol. 50, No. 4, pp.37-46.

Gupta, V., Levenburg, N., Moore, L., Motwani, J. and Schwarz, T. (Eds.) (2008) A Compendium on the Family Business Models around the World, Vol. 10, ICFAI University Press, Hyderabad.

Habbershon, T.G. and Williams, M. (1999) 'A resource-based framework for assessing the strategic advantages of family firms', Family Business Review, Vol. 12, No. 1, pp.1-25.

Habbershon, T.G., Williams, M. and MacMillan, I. (2003) 'A unified systems perspective of family firm performance', Journal of Business Venturing, Vol. 18, No. 4, pp.451-465.

Haberman, H. and Danes, S.M. (2007) 'Father-daughter and father-son family business management transfer comparison: family FIRO model application', Family Business Review, Vol. 20, No. 2, pp.163-184.

Hamilton, E. (2006) 'Whose story is it anyway? Narrative accounts of the role of women in founding and establishing family businesses', International Small Business Journal, Vol. 24, No. 3, pp.253-271.

Harveston, P.D., Davis, P.S. and Lyden, J.A. (1997) 'Succession planning in family business: the impact of owner gender', Family Business Review, Vol. 10, No. 4, pp.373-396.

Haynes, D.C., Avery, R.J. and Hunts, H.J. (1999) 'The decision to outsource child care in households engaged in a family business', Family Business Review, Vol. 12, No. 3, pp.269-281.

Hofstede, G. and Bollinger, D. (1987) Les différences culturelles dans le management, Les Editions d'Organisation, Paris.

Hollander, B.S. and Bukowitz, W.R. (1990) 'Women, family culture and family business', Family Business Review, Vol. 3, No. 2, pp.139-151.

Hopwood, A.G. (1974) Accounting and Human Behaviour, Haymarket Publishing, London.

Huse, M. and Solberg, A.G. (2006) 'Gender-related boardroom dynamics: how Scandinavian women make and can make contributions on corporate boards', Women in Management Review, Vol. 21, No. 2, pp.113-130. 
Jensen, M.C. and Meckling, W.H. (1976) 'Theory of the firm: managerial behavior, agency costs and capital structure', Journal of Financial Economics, Vol. 3, No. 4, pp.305-360.

Jimenez, R.M. (2009) 'Research on women in family firms: current status and future directions', Family Business Review, Vol. 22, No. 1, pp.53-64.

John, G. and Reves, T. (1982) 'The reliability and validity of key informant data from dyadic relationships in marketing channels', Journal of Marketing Research, Vol. 19, No. 4, pp.517-524.

Kanter, R.M. (1977) Men and Women of the Corporation, Basic Books, New York.

Lyman, A., Salangicoff, M. and Hollander, B. (1995) 'Women in family business: an untapped resource', SAM Advanced Management Journal, Vol. 50, No. 1, pp.46-49.

Lyman, A.R. (1988) 'Life in the family circle', Family Business Review, Vol. 1, No. 4, pp.383-398.

Machold, S., Huse, M., Hansen, K. and Brogi, M. (2013) Getting Women on to Corporate Boards. A Snowball Starting in Norway, Edward Elgar Publishing Limited, Cheltenham, UK.

Marshack, K. (1994) 'Co-preneurs and dual-career couples: are they different?', Entrepreneurship Theory and Practice, Vol. 19, No. 1, pp.49-69.

McGivern, C. (1978) 'The dynamics of management succession', Management Decision, Vol. 16, No. 1, pp.32-46.

Moore, D. and Buttner, H. (1997) Women Entrepreneurs. Moving beyond the Glass Ceiling, Sage, Thousand Oaks, CA.

Moores, K. and Mula, J. (2000) 'The salience of market, bureaucratic, and clan controls in the management of family firm transitions: some tentative Australian evidence', Family Business Review, Vol. 13, No. 2, pp.91-106.

Moores, K. and Yuen, S. (2001) 'Management accounting systems and organizational configuration: a life cycle perspective', Accounting, Organizations and Society, Vol. 26, No. 4, pp.351-389.

Morisson, A.M., White, R.P. and Van Velsor, E. (1987) Breaking the Glass Ceiling: Can Women Reach the Top of America's Largest Corporations?, Addison-Wesley, Reading, MA.

Naranjo-Gil, D., Maas, V.S. and Hartmann, F.G.H. (2009) 'How CFOs determine management accounting innovation: an examination of direct and indirect effects', European Accounting Review, Vol. 18, No. 4, pp.667-695.

Nelson, T. and Levesque, L.L. (2007) 'The status of women in corporate governance in high-growth, high-potential firms', Entrepreneurship Theory \& Practice, Vol. 31, No. 2, pp.209-232.

Nelton, S. (1999) 'Why women are chosen to lead?', Nation's Business, Vol. 87, No. 4, pp.48-51.

Nielsen, S. and Huse, M. (2010) 'Women directors' contribution to board decision-making and strategic involvement: the role of equality perception', European Management Review, Vol. 7, No. 1, pp.16-29.

Normann, R. (1977) Management for Growth, John Wiley, Chichester.

Ouchi, W.G. (1979) 'A conceptual framework for the design of organizational control mechanisms', Management Science, September, Vol. 25, No. 9, pp.833-848.

Ouchi, W.G. (1980) 'Markets, bureaucracies and clans', Administrative Science Quarterly, Vol. 25, No. 1, pp.129-141.

Ouchi, W.G. and Price, R.L. (1978) 'Hierarchy, clans and theory Z: a new perspective on organization development', Organizational Dynamics, Vol. 7, No. 2, pp.2-21.

Parkhe, A. (1993) 'Strategic alliance structuring: a game theoretic and transaction cost examination of interfirm cooperation', Academy of Management Journal, Vol. 36, No. 4, pp.794-829.

Pettigrew, A. (1992) 'On studying managerial elites', Strategic Management Journal, Vol. 13, No. 8, pp.163-182.

Podsakoff, P. and Organ, D. (1986) 'Self-reports in organizational research: problems and prospects', Journal of Management, Vol. 12, No. 4, pp.531-544. 
Podsakoff, P.M., MacKenzie, S.B., Lee, J.Y. and Podsakoff, N.P. (2003) 'Common method biases in behavioral research: a critical review of the literature and recommended remedies', Journal of Applies Psychology, Vol. 88, No. 5, pp.879-903.

Powell, G.N. and Butterfield, D.A. (1994) 'Investigating the 'glass ceiling' phenomenon: an empirical study of actual promotions to top management', Academy of Management Journal, Vol. 37, No. 1, pp.68-86.

Powell, T.C. and Dent-Micallef, A. (1997) 'Information technology as competitive advantage: the role of human, business, and technology resources', Strategic Management Journal, Vol. 18, No. 5, pp.375-405.

Poza, E.J. and Messer, T. (2001) 'Spousal leadership and continuity in the family firm', Family Business Review, Vol. 14, No. 1, pp.25-36.

Reid, R.S. and Adams, J.S. (2001) 'Human resource management - a survey of practices within family and non-family firms', Journal of European Industrial Training, Vol. 25, No. 6, pp.310-320.

Reid, R.S., Morrow, T., Kelly, B. and McCartan, P. (2002) 'People Management in SMEs: an analysis of human resource strategies in family and non-family businesses', Journal of Small Business and Enterprise Development, Vol. 9, No. 3, pp.245-259.

Robertson, T.S., Rymon, T. and Eliashberg, J. (1995) 'New product announcement signals and incumbent reactions', Journal of Marketing, Vol. 59, No. 1, pp.1-15.

Rosenblatt, P.C., De Mik, L., Anderson, R.M. and Johnson, P.A. (1985) The Family in Business, Jossey-Bass, San Francisco.

Ross, S. (1973) 'The economic theory of agency: the principal's problem', American Economic Review, Vol. 63, No. 2, pp.134-139.

Rostow, W.W. (1960) The Stages of Economic Growth, Cambridge University Press, Cambridge.

Rowe, B.R. and Hong, G.S. (2000) 'The role of wives in family businesses: the paid and unpaid work of women', Family Business Review, Vol. 13, No. 1, pp.1-13.

Salganicoff, M. (1990) 'Women in family business: challenges and opportunities', Family Business Review, Vol. 3, No. 2, pp.125-137.

Schulze, W.S., Lubatkin, M.H., Dino, R.M. and Bucholtz, A.K. (2001) 'Agency relationships in family firms: theory and evidence', Organization Science, Vol. 12, No. 2, pp.99-116.

Scott, M. and Bruce, R. (1987) 'Five stages of growth in small business', Long Range Planning, Vol. 20, No. 3, pp.45-52.

Sharma, P. (2004) 'An overview of the field of family business studies: current status and directions for the future', Family Business Review, Vol. 17, No. 1, pp.1-36.

Simons, R. (2000) Performance Measurement and Control Systems for Implementing Strategy, Prentice Hall, Englewood Cliffs, NJ.

Singh, V., Terjesen, S. and Vinnicombe, S. (2008) 'Newly appointed directors in the boardroom: how do women and men differ?', European Management Journal, Vol. 26, No. 1, pp.48-58.

Songini, L. (2006) 'The professionalization of family firms: theory and practice', in Poutziouris, P.Z., Smyrnios, K.X. and Klein, S.B. (Eds.): Handbook of Research on Family Business, pp.269-297, Edward Elgar, Cheltenham, UK, Northampton, MA, USA.

Songini, L. and Dubini, P. (2003) 'Glass ceiling in SMEs: when women are in command', Paper presented at the Annual Academy of Management Meeting, Washington, Seattle, August.

Songini, L. and Gnan, L. (2009) 'Women, glass ceiling, and professionalization in family SMEs. A missed link', Journal of Enterprising Culture, Vol. 17, No. 4, pp.497-525.

Songini, L. and Gnan, L. (2013) 'Family involvement and agency cost control mechanisms in family small and medium-sized enterprises', Journal of Small Business Management, forthcoming [online] http://onlinelibrary.wiley.com/doi/10.1111/jsbm.12085/abstract.

Songini, L., Gnan, L. and Malmi, T. (2013) 'The role and impact of accounting in family business', Journal of Family Business Strategy, Vol. 4, No. 2, pp.71-83. 
Speckbacher, G. and Wentges, P. (2007) 'The impact of firm size and family ownership on management control systems in small and medium-sized enterprises', Working article, Wirtschaftuniversitat, Wien.

Stoica, M. and Pistrui, D. (2006) 'Dilemma in family-owned businesses: business commitment vs. family commitment: is success changing the balance?', Journal of Business and Entrepreneurship, Vol. 18, No. 2, pp.1-26.

Tagiuri, R. and Davis, J.A. (1982) 'Bivalent attributes of the family firm', Family Business Review, Vol. 9, pp.199-208, Reprinted (1996).

Torchia, M., Calabrò, A. and Huse, M. (2012) 'Women directors on corporate boards: from tokenism to critical mass', Journal of Business Ethics, Vol. 102, No. 2, pp.299-317.

Tourangeau, R., Rips, L.J. and Rasinski, K. (2000) The Psychology of Survey Response, Cambridge University Press, Cambridge.

Ufuk, H. and Ozgen, O. (2001) 'Interaction between the business and family lives of women entrepreneurs in Turkey', Journal of Business Ethics, Vol. 31, No. 2, pp.95-106.

Veale, C. and Gold, J. (1998) 'Smashing into the glass ceiling for women managers', Journal of Management Development, Vol. 17, No. 1, pp.17-26.

Vera, C.F. and Dean, M.A. (2005) 'An examination of the challenges daughters face in family business succession', Family Business Review, Vol. 18, No. 4, pp.321-346.

Villalonga, B. and Amit, R. (2009) 'How are US family firms controlled?', Review of Financial Studies, Vol. 22, No. 8, pp.3047-3091.

Ward, J.L. and Aronoff, C. (1992) 'Family business: siblings relationship', Nation's Business, Vol. 80, No. 1, p.52.

Westhead, P. and Cowling, M. (1998) 'Family firm research: the need for a methodology rethink', Entrepreneurship Theory and Practice, Fall, Vol. 23, No. 1, pp.31-56.

Zahra, S.A., Neubaum, D.O. and Huse, M. (2000) 'Entrepreneurship in medium size companies: exploring the effects of ownership and governance systems', Journal of Management, Vol. 26, No. 5, pp.947-976.

Zimmerman, J.L. (2006) Accounting for Decision-Making and Control, McGraw Hill, New York.

\section{Notes}

1 SMEs have been defined accordingly to the European Commission Recommendation 2003/361/EC, from 6th May 2003, with effect from 1st January 2005 (published in Official. Journal of the European Union L 124, 20.5.2003, p.36).

2 The Sole CEO is in charge of top management roles, in alternative to the Board of Directors. $\mathrm{He} / \mathrm{she}$ is named Sole CEO under Italian law, owing to the fact that he/she does not belong to any board. Where a Sole CEO is appointed, neither the Board of Directors nor the Chairman exist. 